\title{
DE
} DE GRUYTER OPEN

\section{SOME INSIGHTS ON THE CHANGING ARCHITECTURE OF THE WORLD'S TOP 100 MULTINATIONALS}

\author{
OGREAN Claudia \\ Lucian Blaga University of Sibiu, Romania \\ HERCIU Mihaela \\ Lucian Blaga University of Sibiu, Romania
}

\begin{abstract}
:
Premise: globalization represents both the fertile background and the accountable foreground that accompanies the evolution of TNCS/MNEs, within a self-enforcing spiral of coevolution which gratifies the winners and discards the losers.

Argument: UNCTAD's Top 100 non-financial TNCs/MNEs gathers together, since 1993, some of the most prominent winners of the above mentioned processes, making this instrument one of the best indicators and benchmarks in terms of both globalization and transnationalization - when analyzed at a given moment in time (for a particular year), and even more relevant when analyzed dynamically and by comparison.

Context: two major global shifts have occurred during the last decade or so: the global (financial and) economic crisis and its repercussions, and the rise of the emerging economies and of their TNCS/MNEs.

Aim: to depict the dynamics registered within the world's top 100 non-financial TNCS/MNEs - in order to identify significant insights on how the world of TNCS/MNEs has evolved and its architecture (and inner composition) has changed - by fueling the two shifts mentioned above while internalizing their outcomes.
\end{abstract}

Key words: Transnational Corporations (TNCs) / Multinational Enterprises (MNEs); top 100 non-financial TNCS/MNEs; transnationality dynamics

\section{Introduction}

During the last decades, globalization has represented both the fertile background and the accountable foreground that accompanied the evolution of transnational corporations (TNCs) / multinational enterprises (MNEs), within a selfenforcing spiral of co-evolution which gratifies the winners and discards the losers 
(Dunning, \& Lundan, 2008; Morgan, 2009; McCann, \& Acs, 2011; Forsgren, 2013; Agnew, 2015).

Regardless of the particular approaches and theories concerning the process of firm internationalization (Andersen, 1993; Morgan, \& Katsikeas, 1997; Axinn, \& Matthyssens, 2002; Gabrielsson, et al., 2008; Casillas, \& Acedo, 2013) and the measurement of its intensity/degree (Sullivan, 1994; Ramaswamy, Kroeck, \& Renforth, 1996; Sullivan, 1996; letto-Gillies, 1998; Dörrenbächer, 2000), one thing is for sure: UNCTAD's Top 100 non-financial TNCs/MNEs gathers together, since 1993, some of the most prominent winners of the above mentioned processes - as long as, according to the most recent World Investment Report, "the number of countries in which MNEs in the Top 100 are physically present ranges from fewer than 10 to more than 130 , with an average of more than 50 countries; the Top 100 MNEs tend to be truly global MNEs" (UNCTAD, 2016).

Setting the context of its reports on TNCs/MNEs, UNCTAD (2007) argues that "transnationalization focuses on the intensity of foreign activities in relation to domestic or global activities" (UNCTAD, 2007), while "transnationality is a function of the extent to which a firm's activities are located abroad. It refers to the geographic spread of firms and implies the existence of a home country and one or more host countries" (UNCTAD, 2007). Due to the fact that "the figures for foreign assets, foreign employment and foreign sales, taken in isolation, do not capture fully the extent of involvement of TNCs in the world economy" (UNCTAD, 1995), in 1995 UNCTAD has proposed the Transnationality Index (TNI) and respective rankings of TNCs/MNEs based on this composite index which "is the average of the three shares, the weights being set to one. In other words, the index of transnationality = (foreign assets/total assets + foreign sales/total sales + foreign employment/total employment) divided by 3" (UNCTAD, 1995).

Thus, the world's top 100 non-financial TNCs/MNEs - that UNCTAD releases periodically - is one of the best indicators and benchmarks in terms of both globalization and transnationalization - when analyzed at a given moment in time (for a particular year), and even more relevant when analyzed dynamically and by comparison. Therefore, given two of the major global shifts of the last decade or so the global (financial and) economic crisis and its repercussions (Harris, 2010; Kolasa, Rubaszek, \& Taglioni, 2010; Onwuamaegbu, \& Sauvant, 2011; Alfaro, \& Chen, 2012; Grave, Vardiabasis, \& Yavas, 2012), and the rise of the emerging economies and of their TNCs/MNEs (Goldstein, 2007; Ramamurti, \& Singh, 2009; Guillén, \& GarcíaCanal, 2009; Peng, 2012; Cuervo-Cazurra, \& Ramamurti, (Eds.), 2014) - the dynamics registered within the world's top 100 non-financial TNCs/MNEs could offer significant insights on how the world of TNCs/MNEs has evolved and its architecture (and inner composition) has changed - by fueling the two shifts mentioned above while internalizing their outcomes.

The remainder of the paper is organized as follows: the next (second) section - offering snapshots reflecting the overall dynamics in the world's top 100 non-financial TNCs/MNEs (in terms of - both foreign and total - assets, sales and employment, on 
one hand, and countries represented by their TNCs/MNEs, on the other hand) is complemented by the third, fourth and fifth ones - dedicated to the most significant actors / countries and their particular evolutions (all the analysis are based on data collected from the dedicated Annexes of the UNCTAD's World Investments Reports: 2010 and 2016; while the overall analysis is dealing with amounts and/or averages applicable to all the top 100 non-financial TNCs/MNEs, the in depth analysis takes into consideration the most significant countries - those with at least two TNCs/MNEs in both of the rankings - and their TNCs/MNEs); the sixth section of the paper presents the main conclusions and introduces the future research directions in the field, and the seventh displays its bibliography.

\section{Overall dynamics in the world's top 100 non-financial TNCs/MNEs - 2015 versus 2008}

The evolution of the 100 largest non-financial TNCs/MNEs worldwide, 2008 comparative to 2007 and 2015 comparative to 2014 (Table 1) - which is brought into discussion in order to contextualize the analysis - reveals quite interesting dynamics: 2008 has represented, comparative to 2007, an year of relative (more or less) growth in the absolute value of each one of the variables taken into account (foreign and total assets, foreign and total sales, and foreign and total employment); on the other hand, 2015 has been accompanied by negative percentage changes in terms of foreign and total assets, as well as in terms of foreign and total sales comparative to 2014 - only the employment related variables have registered positive changes. The variation ranges - from 0.2 percentage change to 5.5 percentage change in 2008 comparative to 2007, and from -14.9 percentage change to 9.4 percentage change in 2015 comparative to 2014 - suggest: an inertia as regards the TNCs' behavior against the 2008 global crisis (maybe thanks to their global power) - on one hand; and a struggle to reposition themselves on the new coordinates of the global economy (recovering from the above mentioned crisis and dealing with new global challenges in 2015) - on the other hand.

Table 1 Evolution of the 100 largest non-financial TNCs/MNEs worldwide, 2008 comparative to 2007 and 2015 comparative to 2014

(Billions of dollars, thousands of employees and percentage)

\begin{tabular}{|c|c|c|c|c|c|c|}
\hline \multirow{2}{*}{ Variable } & \multicolumn{3}{|c|}{100 largest TNCs worldwide } & \multicolumn{3}{|c|}{100 largest MNEs worldwide } \\
\hline & 2007 & 2008 & $\%$ change & 2014 & 2015 & $\%$ change \\
\hline \multicolumn{7}{|l|}{ Assets } \\
\hline Foreign & 6116 & 6172 & 0.9 & 8341 & 7933 & -4.9 \\
\hline Total & 10702 & 10760 & 0.9 & 13231 & 12854 & -2.8 \\
\hline Foreign as $\%$ of total & 57 & 57 & 0.2 & 63 & 62 & -1.3 \\
\hline \multicolumn{7}{|l|}{ Sales } \\
\hline Foreign & 4936 & 5173 & 4.8 & 6011 & 5115 & -14.9 \\
\hline Total & 8078 & 8354 & 3.4 & 9042 & 7863 & -13 \\
\hline Foreign as $\%$ of total & 61 & 62 & 0.8 & 66 & 65 & -1.4 \\
\hline Employment & & & & & & \\
\hline
\end{tabular}


Studies in Business and Economics no. 11(3)/2016

\begin{tabular}{|l|l|l|l|l|l|l|}
\hline Foreign & 8440 & 8905 & 5.5 & 9375 & 9973 & 6.4 \\
\hline Total & 14870 & 15408 & 3.6 & 15816 & 17304 & 9.4 \\
\hline Foreign as \% of total & 57 & 58 & 1.0 & 59 & 58 & -1.6 \\
\hline
\end{tabular}

Source: UNCTAD (WIR: 2010; 2016)

A closer comparative look 2015 versus 2008, together with the respective shifts - in terms of: (a). foreign and total assets, sales and employment; (b). contributors to the world's top 100 non-financial TNCs/MNEs (number of TNCs/MNEs by countries) - is offered into Figures 1 to 4.

Fig. 1. The world's top 100 non-financial TNCs/MNEs. Assets in 2015 comparative to 2008 (millions of dollars)

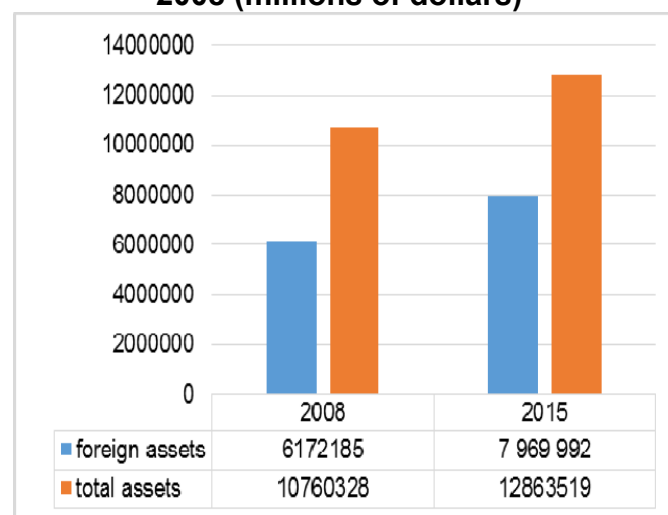

Source: UNCTAD (WIR Annexes: 2010; 2016)

Fig. 2. The world's top 100 non-financial TNCs/MNEs. Sales in 2015 comparative to 2008 (millions of dollars)

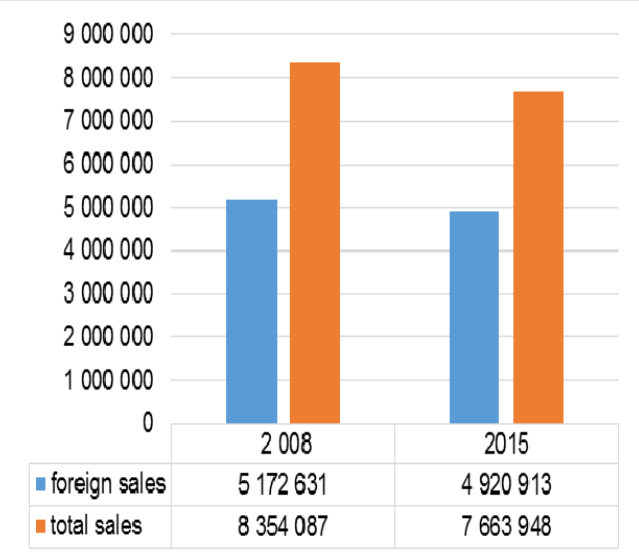

Source: UNCTAD (WIR Annexes: 2010; 2016)
As the data in Fig. 1 reveals for the world's top 100 non-financial TNCs/MNEs, a $19.54 \%$ increase in total assets (in 2015 comparative to 2008) corresponds to a much higher increase $(29.12 \%)$ in foreign assets.

Therefore, while the foreign assets represented $57.36 \%$ of the total assets in 2008 , their share has increased to $61.95 \%$ in 2015.

These shifts reflect an accentuation of transnationality as regards companies' assets, against the background of a lower increase in total assets.

As the data in Fig. 2 reveals for the world's top 100 non-financial TNCs/MNEs, an $8.27 \%$ decrease in total sales (in 2015 comparative to 2008) corresponds to a lower decrease $(4.87 \%)$ in foreign sales.

Therefore, while the foreign sales represented $61.91 \%$ of the total sales in 2008, their share has increased to $64.20 \%$ in 2015.

These shifts reflect an accentuation of transnationality as regards companies' sales, against the background of a decrease in both total sales and foreign sales. 
Fig. 3. The world's top 100 non-financial TNCs/MNEs. Number of employees in 2015 comparative to 2008

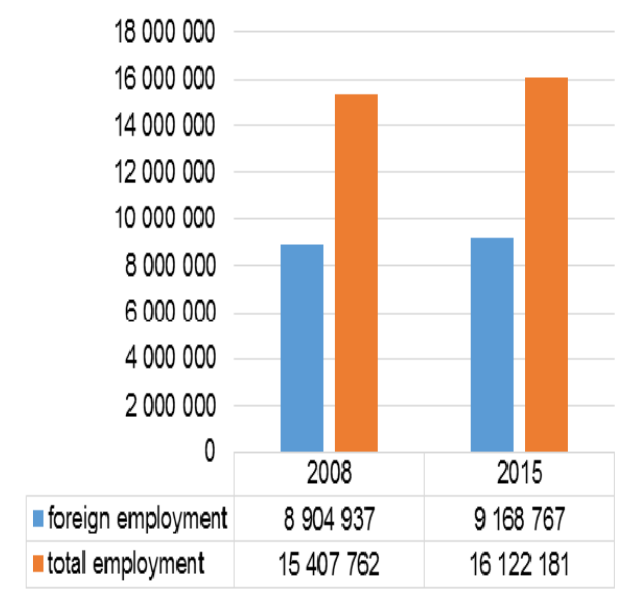

Source: UNCTAD (WIR Annexes: 2010; 2016)
As the data in Fig. 3 reveals for the world's top 100 non-financial TNCs/MNEs, a $4.63 \%$ increase in total employment (in 2015 comparative to 2008) corresponds to a lower increase $(2.96 \%)$ in foreign employment.

Therefore, while the foreign employment represented $57.79 \%$ of the total employment in 2008, their share has decreased to $56.87 \%$ in 2015 .

These shifts reflect an attenuation of transnationality as regards companies' employment, against the background of an increasing of total employment higher than the increasing in foreign employment.

Twenty countries (United States; United Kingdom; France; Germany; Japan; Switzerland; Spain; Sweden; Netherlands; Italy; Korea, Republic of; China; Luxembourg; Hong Kong; Mexico; Norway; Australia; Malaysia; Ireland; and Israel) are represented with their TNCs/MNEs into the world's top 100 non-financial TNCs/MNEs both in 2008 and 2015, while 2 of them (Finland and Portugal) are only present in 2008 and 3 of them (Belgium; Brazil; and Denmark) are only present in 2015 (see the distribution in Fig. 4 and Annex 1).

Fig. 4. Number of TNCs/MNEs in the world's top 100 non-financial TNCs/MNEs by countries - 2015 comparative to 2008

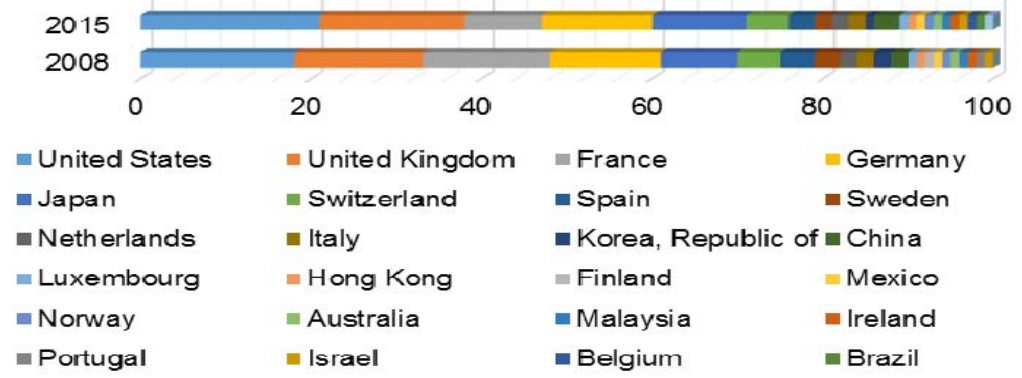

Source: UNCTAD (WIR Annexes: 2010; 2016)

The in deep analysis on the most significant countries / group of countries and their TNCs/MNEs in 2015 comparative to 2008 (taking into account the countries / group of countries with at least 2 TNCs/MNEs in both of the rankings) allows some interesting observations. 


\section{US based TNCs/MNEs in the world's top 100 non-financial TNCs/MNEs}

As regards the United States (US) - the rankings' leader in terms of number of companies both in 2008 and 2015:

- $\quad$ The number of TNCs/MNEs has increased from 18 in 2008 to 21 in 2015;

- 14 TNCs/MNEs are present in both of the rankings (General Electric; ExxonMobil Corporation; Chevron Corporation; Ford Motor Company; ConocoPhillips; Procter \& Gamble; Wal-Mart Stores; IBM; Pfizer Inc.; Hewlett-Packard; General Motors; Johnson \& Johnson; United Technologies Corporation; and Schlumberger Ltd) registering different TNIs, but basically confirming their propensity towards transnationality;

- $\quad$ Among the 14 TNCs/MNEs mentioned above:

$\checkmark 6$ of them have been placed within the same industry in both of the rankings (Ford Motor Company and General Motors: Motor Vehicles; Pfizer Inc. and Johnson \& Johnson: Pharmaceuticals; United Technologies Corporation: Aircraft; Wal-Mart Stores: Retail \& Trade / Retail Trade);

$\checkmark \quad 8$ of them are registered within different industries in 2015 comparative to 2008 (General Electric: Industrial and Commercial Machinery versus Electrical \& Electronic equipment; ExxonMobil Corporation, Chevron Corporation and ConocoPhillips: Petroleum Refining and Related Industries versus Petroleum expl./ref./distr; Procter \& Gamble: Chemicals and Allied Products versus Diversified; IBM and Hewlett-Packard: Computer and Data Processing versus Electrical \& Electronic equipment; and Schlumberger Ltd: Mining, quarrying and petroleum versus Other consumer services); these industry changes suggests either a higher specialization, or an accentuated diversification in terms of strategy;

- $\quad 4$ of the TNCs/MNEs which were present in 2008 have disappeared from top 100 in 2015 (Liberty Global Inc.: Telecommunication; Alcoa: Metal and metal products; Kraft Foods Inc. and Coca-Cola Company: Food, beverages and tobacco), while 8 TNCs/MNEs have replaced them in 2015 (Apple Computer Inc.: Computer equipment; Microsoft Corporation, Oracle Corporation and Alphabet Inc.: Computer and Data Processing; Pfizer Inc. and Amgen Inc.: Pharmaceuticals; Mondelez International, Inc.: Food \& beverages; Caterpillar Inc.: Industrial and Commercial Machinery);

- In comparison to the global (average) dynamics and trends, the US TNCs/MNEs register:

$\checkmark$ lower than the average levels regarding the foreign assets, foreign sales and foreign employment in total (assets, sales and employment) - for both of the reference years, as well as a decreasing tendency as concerns each particular category - despite the increasing tendency in the contribution of the foreign assets and foreign sales to the total assets and total sales respectively, registered on average (Fig. 5); 
Fig. 5 Distribution of foreign assets, foreign sales and foreign employment
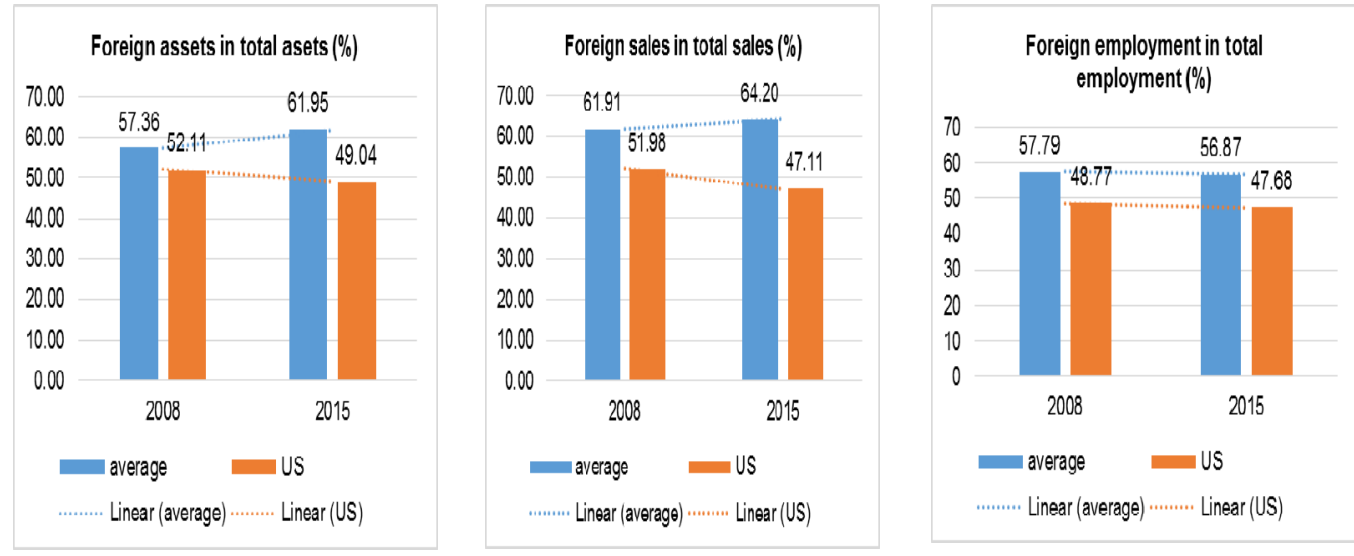

Source: UNCTAD (WIR Annexes: 2010; 2016)

$\checkmark$ higher than the average increasing levels in terms of both total and foreign employment (with a less accentuated increase of foreign employment, but quite significant when compared to the average); a slightly lower than the average decrease of total sales, accompanied by a much more pronounced than the average decrease of foreign assets; a lower than the average increase in foreign assets, registered against the background of a significant increase in total assets (comparative to the average) (Fig. 6).

Fig. 6 Variations among categories in 2015 comparative to 2008 (\%)

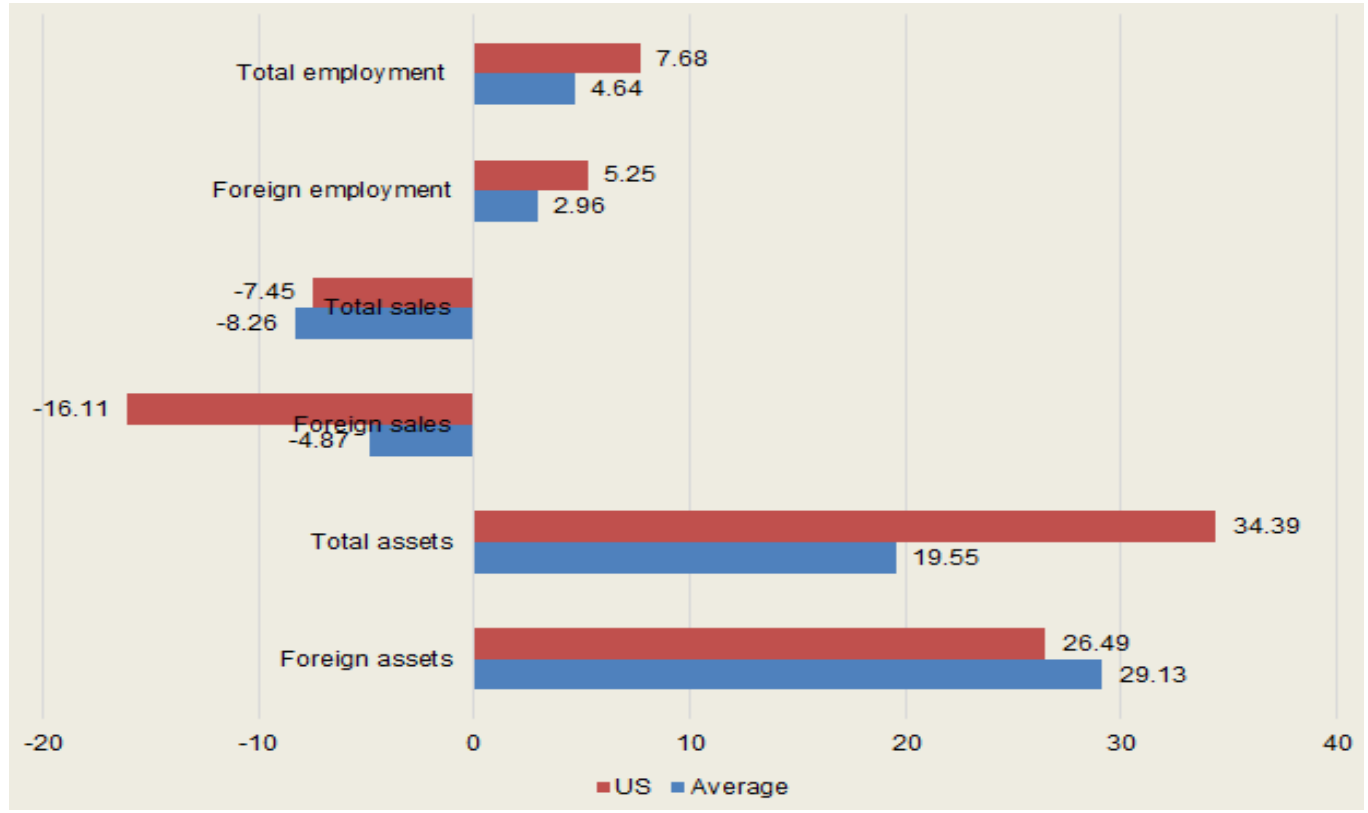

Source: UNCTAD (WIR Annexes: 2010; 2016) 


\section{European based TNCs/MNEs in the world's top 100 non-financial TNCs/MNEs}

As regards the European countries which are present in "top 10" (United Kingdom - UK, France, Germany, Switzerland, Spain, Sweden, Netherlands, and Italy), and their TNCs/MNEs:

- $\quad$ The number of TNCs/MNEs has decreased from 59 in 2008 to 53 in 2015;

- Some of the corporations are present in both of the rankings, certifying their transnationality; by countries, and considering their industry affiliation in 2015 , the following TNCs/MNEs respond to this criterion:

$\checkmark 13$ UK based TNCs/MNEs (out of the 15 TNCs/MNEs in 2008 and 17 in 2015):

- 4 corporations operating within the Mining, quarrying and petroleum industry: Royal Dutch Shell plc, Rio Tinto PLC, BG Group plc, and Anglo American plc;

- 3 corporations operating within the Food \& beverages industry: Unilever PLC, Diageo PLC, and SABMiller PLC;

- 2 corporations operating within the Pharmaceuticals industry: GlaxoSmithKline PLC, and AstraZeneca PLC;

- and one corporation operating within each one of the following industries: Petroleum Refining and Related Industries: BP plc; Telecommunications: Vodafone Group Plc.; Electricity, gas and water: National Grid PLC; and Business Services: WPP PLC.

$\checkmark 10$ Germany based TNCs/MNEs (out of the 13 TNCs/MNEs present both in 2008 and 2015):

- 3 corporations operating within the Motor Vehicles industry: Volkswagen Group, Daimler AG, and BMW AG;

- 2 corporations operating within the following 2 industries: Chemicals and Allied Products: BASF SE, and Linde AG; and Electricity, gas and water: E.ON AG, and RWE AG;

- and one corporation operating within each one of the following industries: Industrial and Commercial Machinery: Siemens AG; Telecommunications: Deutsche Telekom AG; Pharmaceuticals: Bayer AG.

$\checkmark \quad 4$ Switzerland based TNCs/MNEs (out of the 5 TNCs/MNEs present both in 2008 and 2015): Novartis AG and Roche Group - Pharmaceuticals; Nestlé SA - Food, beverages and tobacco; and Holcim AG (Non-metallic mineral products in 2008) which has become Lafargeholcim Ltd (Stone, Clay, Glass, and Concrete Products in 2015).

$\checkmark 3$ France based TNCs/MNEs (out of the 15 TNCs/MNEs in 2008 and 9 in 2015): Total SA - Petroleum Refining and Related Industries; EDF SA Electricity, gas and water; and Sanofi - Pharmaceuticals. 
$\checkmark \quad 3$ Spain based TNCs/MNEs (out of the 4 TNCs/MNEs in 2008 and 3 in 2015): Telefonica SA - Telecommunications; Iberdrola SA - Electricity, gas and water; and Repsol YPF SA - Petroleum Refining and Related Industries.

$\checkmark 2$ Sweden based TNCs/MNEs (out of the 3 TNCs/MNEs in 2008 and 2 in 2015): Vattenfall AB - Electricity, gas and water; and Volvo AB - Motor Vehicles.

$\checkmark \quad 1$ Italy based TNC/MNE (out of the 2 TNCs/MNEs present both in 2008 and 2015): Eni SpA - Petroleum Refining and Related Industries.

$\checkmark$ none of the 2 Netherland based TNCs/MNEs (out of the 2 TNCs/MNEs present both in 2008 and 2015).

- As regard the "process losses", the following TNCs/MNEs have left the top 100 (in 2015, comparative to 2008):

$\checkmark \quad 12$ France based TNCs/MNEs: GDF Suez and Veolia Environnement SA Utilities (Electricity, gas and water); France Telecom and Vivendi Universal - Telecommunications; Lafarge SA and Compagnie De Saint-Gobain SA Non-metallic mineral products; Pinault-Printemps Redoute SA and Carrefour SA - Retail \& Trade; Eads NV - Aircraft; Air Liquide Chemical/Non-metallic mineral products; Pernod Ricard SA - Food, beverages and tobacco; and Lvmh Moët-Hennessy Louis Vuitton SA Other consumer goods.

$\checkmark \quad 3$ Germany based TNCs/MNEs: Thyssenkrupp AG - Metal and metal products; Deutsche Post AG - Transport and storage; and Metro AG Retail \& Trade.

$\checkmark \quad 2$ UK based TNCs/MNEs: Xstrata PLC (Mining \& quarrying) and BAE Systems Plc (Aircraft); and 2 Netherlands based TNCs/MNEs: AnheuserBusch Inbev SA (Food, beverages and tobacco), and Philips Electronics (Electrical \& electronic equipment).

$\checkmark \quad 1$ Spain based TNC/MNE: Grupo Ferrovial (Construction and real estate); 1 Sweden based TNC/MNE: TeliaSonera AB (Telecommunications); 1 Switzerland based TNC/MNE: ABB Ltd. (Engineerig services); and 1 Italy based TNC/MNE: Fiat Spa (Motor vehicles).

- $\quad$ As regard the new entries (in 2015 comparative to 2008), they (and their respective industries) are:

$\checkmark \quad 6$ France based TNCs/MNEs: Engie (Electricity, gas and water); Airbus Group NV (Aircraft); Orange SA (Telecommunications); Christian Dior SA (Textiles, clothing and leather); Schneider Electric SA (Electricity, gas and water); and Renault SA (Motor Vehicles);

$\checkmark \quad 4$ UK based TNCs/MNEs: Imperial Brands PLC and British American Tobacco PLC (Tobacco); Fiat Chrysler Automobiles (Motor Vehicles); and Liberty Global plc (Telecommunications); 
$\checkmark \quad 3$ Germany based TNCs/MNEs: Robert Bosch GmbH (Motor Vehicles); SAP SE (Computer and Data Processing); and Fresenius SE \& Co KGaA (Health care services);

$\checkmark 2$ Netherlands based TNCs/MNEs: Altice NV (Telecommunications) and Heineken NV (Food \& beverages);

$\checkmark \quad 1$ Switzerland based TNC/MNE: Glencore Xstrata PLC (Mining, quarrying and petroleum) and 1 Italy based TNC/MNE: Enel SpA (Electricity, gas and water).

- In comparison to the global dynamics and trends and, the European "top 10" countries register:

$\checkmark$ higher than the average levels regarding the contribution of foreign assets, foreign sales and foreign employment in total (assets, sales and employment) - for both of the reference years, accompanied by an increasing tendency (more pronounced than the average increasing tendency) in terms of contribution of foreign assets and foreign sales in total assets and total sales respectively - on one hand, and a decreasing tendency (more accentuated than the average) in terms of contribution of foreign employment in total employment - on the other hand (Fig. 7);

Fig. 7 Distribution of foreign assets, foreign sales and foreign employment
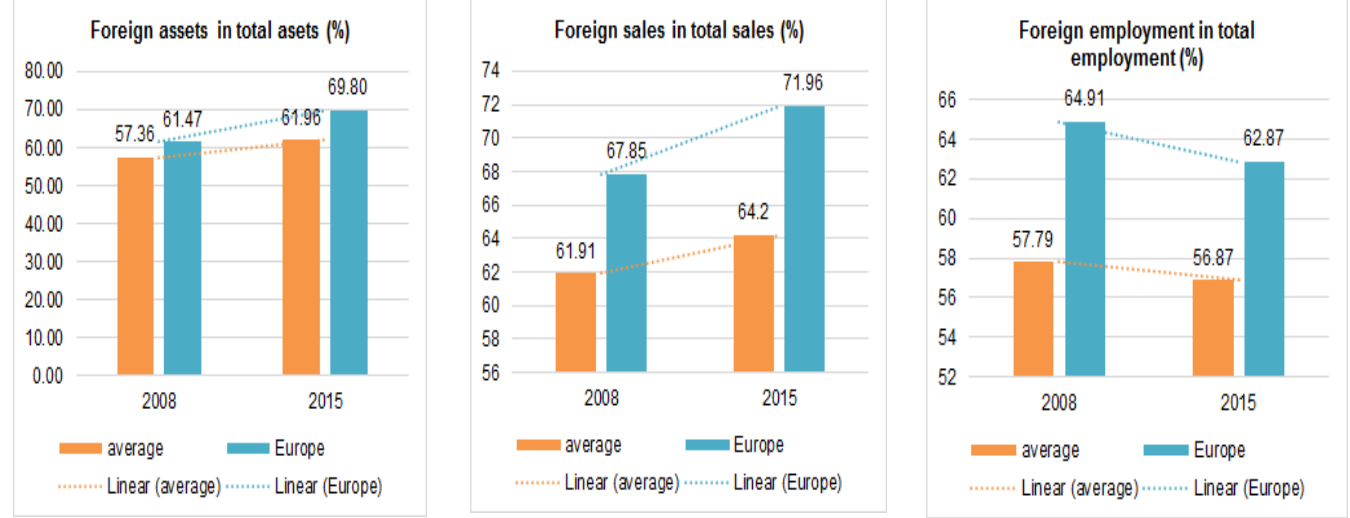

Source: UNCTAD (WIR Annexes: 2010; 2016)

$\checkmark$ much lower than the average increasing levels in terms of both total and foreign assets (while the foreign assets of the European TNCs/MNEs - part of the analysis group - have increased with about a half less than the average, their total assets have only increased one tenth in comparison to the average increase in total assets); a much more pronounced than the average decrease of both total sales and foreign sales (the total sales registering a higher decrease); significant decreasing in terms of both total and foreign employment (more pronounced as regard the foreign employment) - against the background of a slightly average increase of both categories (Fig. 8). 
Fig. 8 Variations among categories in 2015 comparative to 2008 (\%)

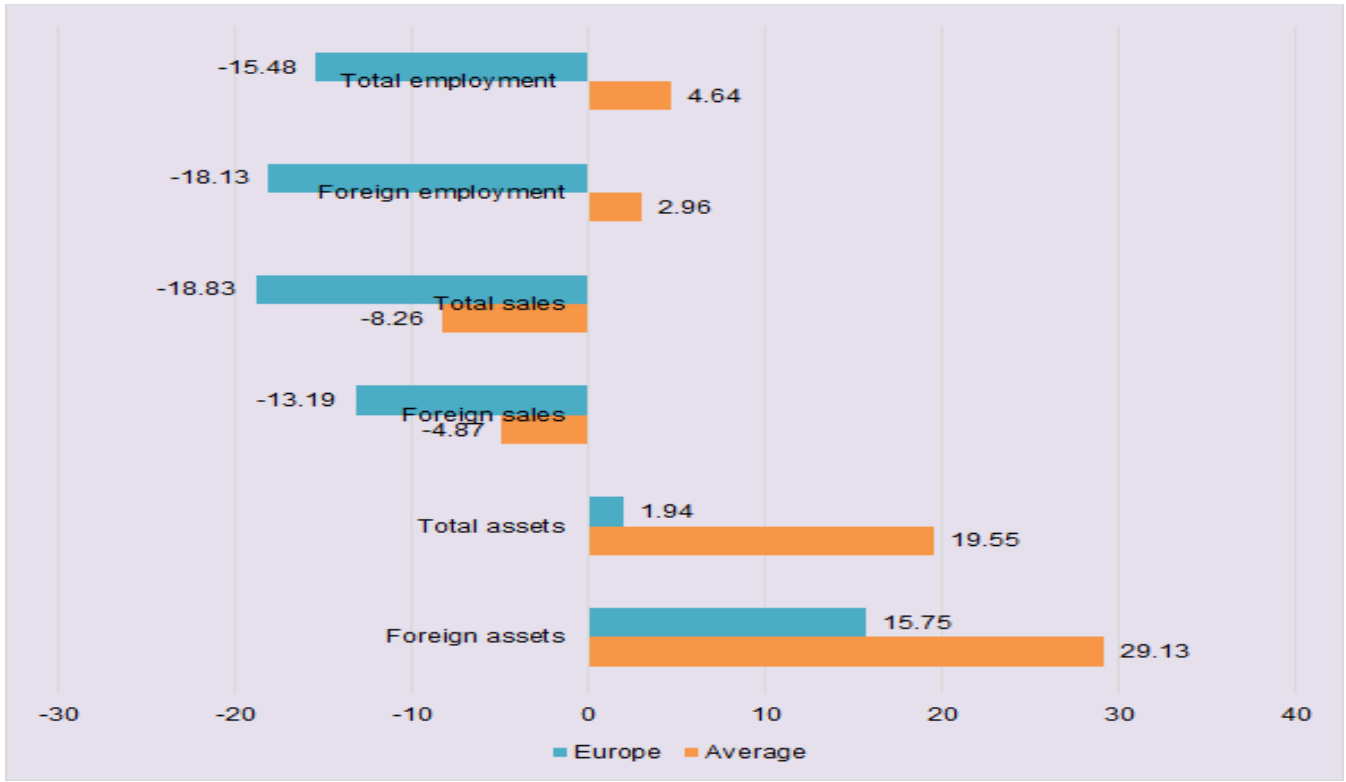

Source: UNCTAD (WIR Annexes: 2010; 2016)

\section{Japanese and Chinese TNCs/MNEs in the world's top 100 non- financial TNCs/MNEs}

As regards Japan in its capacity of major contributor to the top 100 nonfinancial TNCs/MNEs:

- The number of TNCs/MNEs has increased from 9 in 2008 to 11 in 2015;

- $\quad$ All the 9 TNCs/MNEs from 2008 have kept their presence into the 2015's top 100 (some of them registering different industry affiliation): Toyota Motor Corporation, Honda Motor Co Ltd, and Nissan Motor Co Ltd - Motor Vehicles industry; Mitsubishi Corporation, Marubeni Corporation and Sumitomo Corporation Wholesale Trade; Mitsui \& Co Ltd - Mining, quarrying and petroleum in 2015, while Wholesale Trade in 2008; Sony Corporation - Electric equipment in 2015, while Electrical \& electronic equipment in 2008; and Hitachi Ltd - Computer Equipment in 2015, while Electrical \& electronic equipment in 2008;

- The new comers in 2015 comparative to 2008 are: Softbank Corp Telecommunications; and ITOCHU Corporation - Wholesale Trade;

- In comparison to the global (average) dynamics and trends, the Japanese TNCs/MNEs register:

$\checkmark$ lower than the average levels of foreign assets, foreign employment and especially foreign sales in total assets, employment and sales - in 2008, followed by: a significant narrowing of the gaps - as regards the share of foreign employment in total employment (against the background of an average decreasing of the level of foreign employment in total employment), and especially as regards the share of foreign sales in total 
sales -, and a higher than the average presence of foreign assets in total assets - in 2015 (Fig. 9);

Fig. 9 Distribution of foreign assets, foreign sales and foreign employment
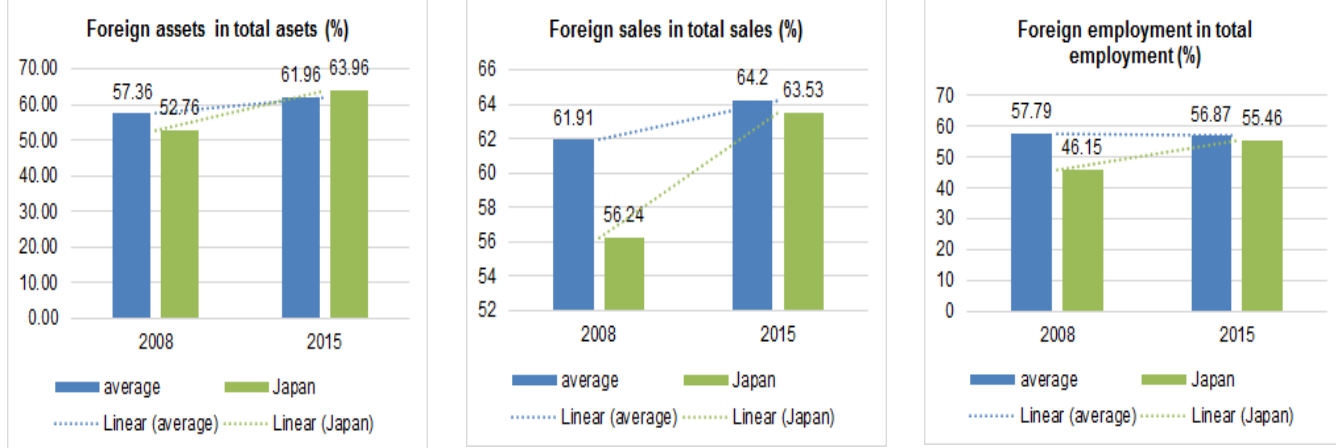

Source: UNCTAD (WIR Annexes: 2010; 2016)

$\checkmark$ much more higher than the average positive dynamics in terms of foreign and total assets (with a particular emphasis on the evolution of foreign assets), as well as in terms of total and especially foreign employment, accompanied also by consistent positive dynamics in terms of total sales and especially of foreign sales (despite the general decreasing tendency registered by the foreign sales and especially by the total sales) (Fig. 10).

Fig. 10 Variations among categories in 2015 comparative to 2008 (\%)

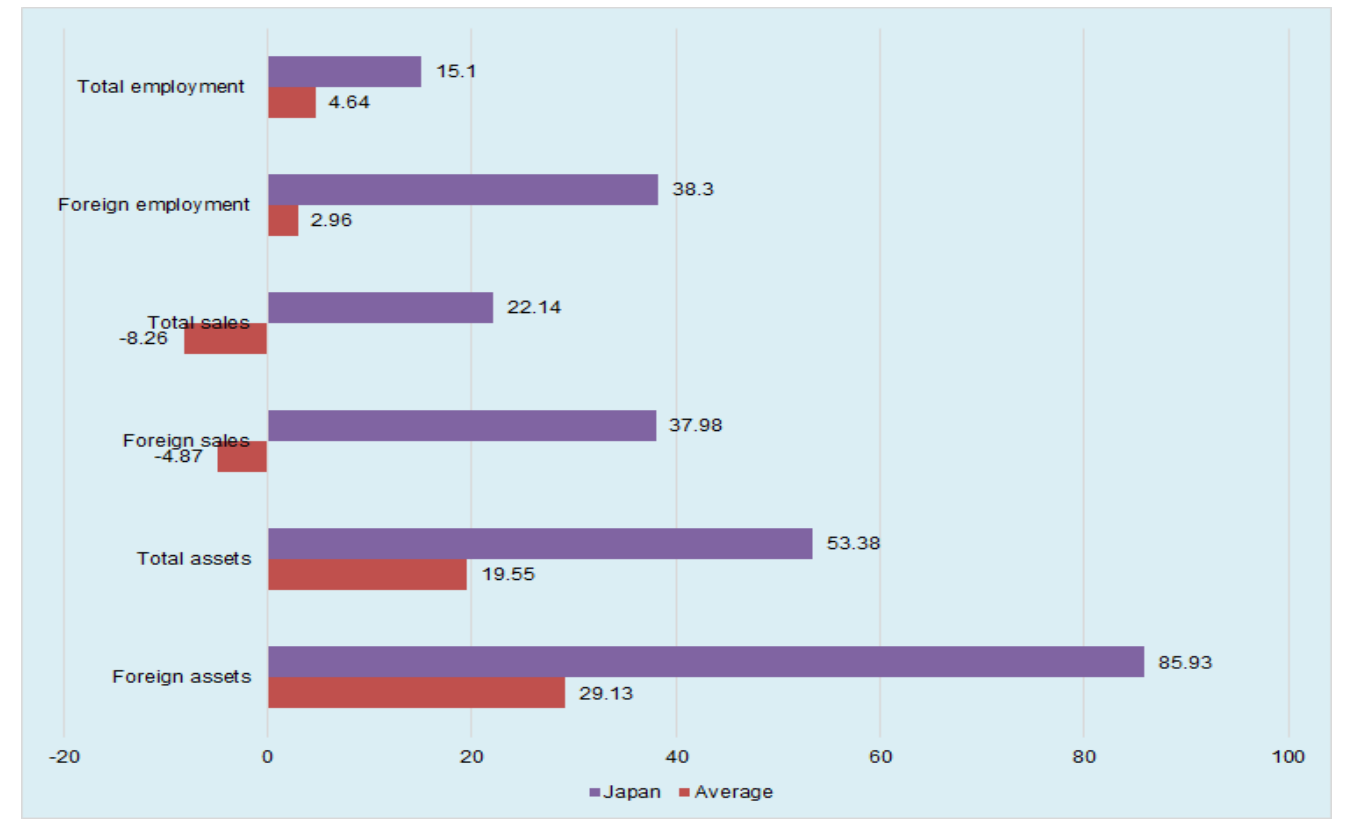

Source: UNCTAD (WIR Annexes: 2010; 2016) 
Last, but not least on the short list of the countries with TNCs/MNEs into the Top 100 non-financial TNCs/MNEs (those countries with at least two corporations present in both of the rankings - 2008 and 2015 respectively), China is defined by the following:

- $\quad$ The number of TNCs/MNEs has increased from 2 in 2008 to 3 in 2015;

- $\quad$ One of the 2 TNCs/MNEs from 2008 has kept its presence into the 2015's top 100 - China Ocean Shipping (Group) Company - belonging to Transport and storage industry; one of the TNCs/MNEs from 2008 has left the top 100 CITIC Group belonging to Diversified industry, while 2 new corporations have entered into the 2015's top 100: China National Offshore Oil Corp - Mining, quarrying and petroleum, and Hon Hai Precision Industries - Electronic components;

- In comparison to the global (average) dynamics and trends, the Chinese TNCs/MNEs register:

$\checkmark \quad$ lower than the average levels regarding the share of foreign sales, foreign assets and especially foreign employment in total (assets, sales and employment) in 2008, followed by bold increasing tendencies towards transnationality, which were reflected in 2015 in: much diminished gaps comparative to the average as regards the share of foreign assets and foreign employment in total assets and employment respectively, as well as in a higher than the average presence of foreign sales (Fig. 11);

Fig. 11 Distribution of foreign assets, foreign sales and foreign employment
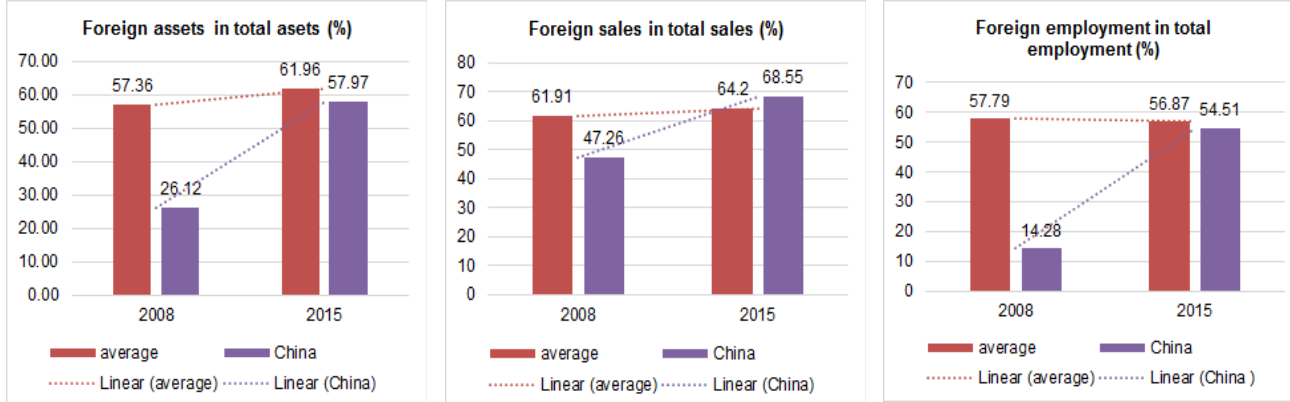

Source: UNCTAD (WIR Annexes: 2010; 2016)

$\checkmark$ extraordinary dynamics as regards the absolute value of each one of the six categories taken into account: the rather modest increase of both foreign and total employment that characterizes the Top 100 average is totally left behind by the increase registered by the Chinese TNCs/MNEs in terms of total, and especially foreign employment; the decrease of both total and foreign sales that characterizes the Top 100 average is completely overwhelmed by the increase of total and especially foreign sales registered by the Chinese TNCs/MNEs; the quite significant increase of foreign assets that characterizes the Top 100 average is by far surpassed by the increase registered by the Chinese TNCs/MNEs, while 
the category total assets is the only one with a more modest than average increase (Table 2).

Table 2 Variations among categories in 2015 comparative to 2008 (\%)

\begin{tabular}{|l|c|c|c|c|c|c|}
\hline & $\begin{array}{c}\text { Foreign } \\
\text { assets }\end{array}$ & $\begin{array}{c}\text { Total } \\
\text { assets }\end{array}$ & $\begin{array}{c}\text { Foreign } \\
\text { sales }\end{array}$ & $\begin{array}{c}\text { Total } \\
\text { sales }\end{array}$ & $\begin{array}{c}\text { Foreign } \\
\text { employment }\end{array}$ & $\begin{array}{c}\text { Total } \\
\text { employment }\end{array}$ \\
\hline Top 100 Average & 129.13 & 119.55 & 95.13 & 91.74 & 102.96 & 104.64 \\
\hline China & 250.55 & 112.88 & 783.16 & 539.88 & 2982.38 & 781.13 \\
\hline
\end{tabular}

Source: UNCTAD (WIR Annexes: 2010; 2016)

\section{Conclusions}

The dynamic (in time) and comparative (in space) analysis of the world's Top 100 non-financial TNCs/MNEs reveals a series of (more or less expected) changes from 2008 to 2015 - in terms of: overall dynamics (quite surprising when contextualizing the analysis by introducing the data from 2007 and 2014 respectively); number of multinationals present in the two rankings, process loses and new entries by country / group of countries and industries; contribution of foreign assets, sales and employment to total assets, sales and employment and variations among categories by country / group of countries and comparative to the total / average.

Some of the country / group of countries data are consistent with the general / average dynamics, while in other cases, the evolutions are quite different - there is no one size fits all kind of behavioral pattern. Besides the insights emphasized within the previous sections, some more subtle changes have been detected - in terms of: (1). results of strategic decisions such as mergers and acquisitions (the case of Lafarge, a French corporation in 2008, and Holcim, a Switzerland corporation in 2008, which become Switzerland Lafargeholcim corporation in 2015); and (2). home economy (at least two companies are present in both of the rankings, but positioned within two different home economies: Liberty Global - as US corporation in 2008 and as UK corporation in 2015; Fiat - as Italian corporation in 2008 and as UK corporation, under the name of Fiat Chrysler Automobiles, in 2015). These (and probably other similar situations) need a further closer look.

Future research - relative to the same sample of global business players - will focus on identifying and analyzing: the evolution of a country's TNCs/MNEs' transnationality index - comparative to the average and in relationship with its inner determinants and main effects; industry related dynamics - by groups of countries and in terms of contributions to total/average values - while concentrating on major shifts (due to strategic decisions such as disinvestments, mergers and acquisitions).

\section{References}

Agnew, J. (2015). The new global economy: time-space compression, geopolitics, and global uneven development. Journal Of World-Systems Research, 7(2), 133-154. 
Alfaro, L., \& Chen, M. X. (2012). Surviving the global financial crisis: foreign ownership and establishment performance. American Economic Journal: Economic Policy, 4(3), 30-55.

Andersen, O. (1993). On the internationalization process of firms: A critical analysis. Journal of International Business Studies, 24(2), 209-231.

Axinn, C. N., \& Matthyssens, P. (2002). Limits of internationalization theories in an unlimited world. International Marketing Review, 19(5), 436-449.

Casillas, J. C., \& Acedo, F. J. (2013). Speed in the internationalization process of the firm. International Journal of Management Reviews, 15(1), 15-29.

Cuervo-Cazurra, A., \& Ramamurti, R. (Eds.). (2014). Understanding multinationals from emerging markets. Cambridge University Press.

Dörrenbächer, C. (2000). Measuring corporate internationalisation. Intereconomics, 35(3), 119126.

Dunning, J. H., \& Lundan, S. M. (2008). Multinational enterprises and the global economy. Edward Elgar Publishing.

Forsgren, M. (2013). Theories of the multinational firm: A multidimensional creature in the global economy. Edward Elgar Publishing.

Gabrielsson, M., Kirpalani, V. M., Dimitratos, P., Solberg, C. A., \& Zucchella, A. (2008). Born globals: Propositions to help advance the theory. International Business Review, 17(4), 385-401.

Goldstein, A. (2007). Multinational companies from emerging economies: composition, conceptualization and direction in the global economy. Springer.

Grave, K., Vardiabasis, D., \& Yavas, B. (2012). The global financial crisis and M\&A. International Journal of Business and Management, 7(11), 56.

Guillén, M. F., \& García-Canal, E. (2009). The American model of the multinational firm and the "new" multinationals from emerging economies. The Academy of Management Perspectives, 23(2), 23-35.

Harris, J. (2010). The world economic crisis and transnational corporations. Science \& Society, 74(3), 394-409.

letto-Gillies, G. (1998). Different conceptual frameworks for the assessment of the degree of internationalization: an empirical analysis of various indices for the top 100 transnational corporations. Transnational corporations, 7, 17-40.

Kolasa, M., Rubaszek, M., \& Taglioni, D. (2010). Firms in the great global recession: The role of foreign ownership and financial dependence. Emerging Markets Review, 11(4), 341357.

McCann, P., \& Acs, Z. J. (2011). Globalization: countries, cities and multinationals. Regional Studies, 45(1), 17-32.

Morgan, G. (2009). Globalization, multinationals and institutional diversity. Economy and Society, 38(4), 580-605.

Morgan, R. E., \& Katsikeas, C. S. (1997). Theories of international trade, foreign direct investment and firm internationalization: a critique. Management Decision, 35(1), 68-78.

Onwuamaegbu, U., \& Sauvant, K. (2011). FDI, the global crisis and sustainable recovery. Transnational Corporations, 20(1), 1-18.

Peng, M. W. (2012). The global strategy of emerging multinationals from China. Global Strategy Journal, 2(2), 97-107.

Ramaswamy, K., Kroeck, K. G., \& Renforth, W. (1996). Measuring the degree of internationalization of a firm: A comment. Journal of International Business Studies, 27(1), 167-177

Ramamurti, R., \& Singh, J. V. (2009). Emerging multinationals in emerging markets. Cambridge University Press. 
Sullivan, D. (1996). Measuring the degree of internationalization of a firm: A reply. Journal of International Business Studies, 179-192.

Sullivan, D. (1994). Measuring the degree of internationalization of a firm. Journal of International Business Studies, 25(2), 325-342.

UNCTAD (1995). World Investment Report 1995 Transnational Corporations and Competitiveness. http://unctad.org/en/Docs/wir1995_en.pdf

UNCTAD (2007). The Universe of the Largest Transnational Corporations. http://unctad.org/en/Docs/iteiia20072_en.pdf.

UNCTAD (2010). World Investment Report 2010. Investing in a low-carbon economy. http://unctad.org/en/Docs/wir2010_en.pdf

UNCTAD (2010). World Investment Report (WIR). Annex table 26. The world's top 100 nonfinancial TNCs, ranked by foreign assets, 2008. unctad.org/Sections/dite_dir/docs/wir2010_anxtab26.xls.

UNCTAD (2016). World Investment Report 2016. Investor Nationality: Policy Challenges. http://unctad.org/en/PublicationsLibrary/wir2016_en.pdf

UNCTAD (2016). World Investment Report (WIR). Annex table 24. The world's top 100 nonfinancial MNEs, ranked by foreign assets, 2015. http://unctad.org/en/Pages/DIAE/World\%20Investment\%20Report/Annex-Tables.aspx.

Annex 1.

\begin{tabular}{|c|c|c|c|c|c|c|c|c|}
\hline \multirow[t]{2}{*}{ Country } & \multirow{2}{*}{\multicolumn{2}{|c|}{$\begin{array}{c}\text { No of } \\
\text { TNCs/MNEs }\end{array}$}} & \multicolumn{2}{|c|}{$\begin{array}{c}\text { Assets } \\
\text { (Millions of dollars) }\end{array}$} & \multicolumn{2}{|c|}{$\begin{array}{c}\text { Sales } \\
\text { (Millions of dollars) }\end{array}$} & \multicolumn{2}{|c|}{$\begin{array}{l}\text { Employment } \\
\text { (Employees) }\end{array}$} \\
\hline & & & Foreign & Total & Foreign & Total & Foreign & Total \\
\hline \multirow{2}{*}{ United States } & 2008 & 18 & 1367779 & 2624917 & 1280179 & 2462958 & 2304226 & 4724455 \\
\hline & 2015 & 21 & 1730042 & 3527665 & 1073973 & 2279517 & 2425302 & 5087071 \\
\hline \multirow{2}{*}{ United Kingdom } & 2008 & 15 & 1028467 & 1313642 & 874797 & 1273239 & 904871 & 1179449 \\
\hline & 2015 & 17 & 1396516 & 1677235 & 753190 & 1018502 & 1116628 & 1465384 \\
\hline \multirow{2}{*}{ France } & 2008 & 15 & 909320 & 1496993 & 658266 & 1002900 & 1433356 & 2252318 \\
\hline & 2015 & 9 & 745679 & 1264484 & 414538 & 597035 & 706664 & 1233605 \\
\hline \multirow{2}{*}{ Germany } & 2008 & 13 & 858518 & 1863166 & 767984 & 1206628 & 1508869 & 2731673 \\
\hline & 2015 & 13 & 998322 & 1716981 & 775955 & 1138069 & 1365719 & 2673672 \\
\hline \multirow{2}{*}{ Japan } & 2008 & 9 & 556561 & 1054858 & 424413 & 754662 & 632649 & 1370772 \\
\hline & 2015 & 11 & 1034856 & 1617941 & 585621 & 921802 & 875011 & 1577839 \\
\hline \multirow{2}{*}{ Switzerland } & 2008 & 5 & 224935 & 325353 & 230090 & 243651 & 544937 & 666110 \\
\hline & 2015 & 5 & 406685 & 540709 & 324393 & 389249 & 651594 & 827753 \\
\hline \multirow{2}{*}{ Spain } & 2008 & 4 & 256063 & 394384 & 131034 & 226786 & 297586 & 427666 \\
\hline & 2015 & 3 & 255563 & 317098 & 90842 & 131367 & 125855 & 185861 \\
\hline \multirow{2}{*}{ Sweden } & 2008 & 3 & 97937 & 137990 & 70290 & 86706 & 116750 & 164218 \\
\hline & 2015 & 2 & 72218 & 103414 & 50385 & 56597 & 87760 & 117031 \\
\hline \multirow{2}{*}{ Netherlands } & 2008 & 2 & 138922 & 159157 & 55821 & 62161 & 192371 & 241272 \\
\hline & 2015 & 2 & 108264 & 111814 & 38124 & 38909 & 105987 & 111273 \\
\hline \multirow{2}{*}{ Italy } & 2008 & 2 & 136670 & 248242 & 161380 & 245103 & 155377 & 277228 \\
\hline & 2015 & 2 & 242922 & 322830 & 91973 & 159137 & 59540 & 96967 \\
\hline \multirow{2}{*}{ China } & 2008 & 2 & 71816 & 274977 & 23468 & 49661 & 22886 & 160298 \\
\hline & 2015 & 3 & 179935 & 310401 & 183792 & 268110 & 682547 & 1252140 \\
\hline \multirow{2}{*}{ Korea, Republic of } & 2008 & 2 & 57125 & 165810 & 122766 & 182844 & 99302 & 239970 \\
\hline & 2015 & 1 & 62294 & 205860 & 158756 & 177134 & 219822 & 319208 \\
\hline \multirow{2}{*}{ Luxembourg } & 2008 & 1 & 127127 & 133088 & 112689 & 124936 & 239455 & 315867 \\
\hline & 2015 & 1 & 74161 & 76846 & 63493 & 63578 & 125175 & 209000 \\
\hline \multirow{2}{*}{ Hong Kong, China } & 2008 & 1 & 70762 & 87745 & 25006 & 30236 & 182148 & 220000 \\
\hline & 2015 & 1 & 118250 & 133280 & 17224 & 21511 & 239552 & 270000 \\
\hline \multirow{2}{*}{ Finland } & 2008 & 1 & 50006 & 55090 & 73662 & 74192 & 101559 & 125829 \\
\hline & 2015 & 0 & - & - & - & - & - & - \\
\hline \multirow{2}{*}{ Mexico } & 2008 & 1 & 40258 & 45084 & 17982 & 21830 & 41586 & 56791 \\
\hline & 2015 & 1 & 35790 & 74624 & 36666 & 56298 & 107672 & 191156 \\
\hline Norway & 2008 & 1 & 37977 & 82645 & 28328 & 116318 & 11495 & 29496 \\
\hline
\end{tabular}


Studies in Business and Economics no. 11(3)/2016

\begin{tabular}{|l|r|r|r|r|r|r|r|r|}
\hline & 2015 & 1 & 61854 & 109596 & 13835 & 57647 & 2604 & 21581 \\
\hline \multirow{2}{*}{ Australia } & 2008 & 1 & 34393 & 78770 & 34784 & 50211 & 24730 & 40990 \\
\cline { 2 - 9 } & 2015 & 1 & 62274 & 124580 & 42431 & 44636 & 21415 & 42829 \\
\hline \multirow{2}{*}{ Malaysia } & 2008 & 1 & 28447 & 106416 & 32477 & 77094 & 7847 & 39236 \\
\cline { 2 - 9 } & 2015 & 1 & 45572 & 153770 & 76726 & 100602 & 5790 & 50949 \\
\hline \multirow{2}{*}{ Ireland } & 2008 & 1 & 27787 & 29396 & 28926 & 30559 & 46248 & 93572 \\
\cline { 2 - 9 } & 2015 & 1 & 99535 & 135841 & 12884 & 15071 & 22860 & 31200 \\
\hline \multirow{2}{*}{ Portugal } & 2008 & 1 & 27104 & 49699 & 7679 & 20328 & 4543 & 12245 \\
\cline { 2 - 9 } & 2015 & 0 & - & - & - & - & - & - \\
\hline \multirow{2}{*}{ Israel } & 2008 & 1 & 24213 & 32904 & 10609 & 11085 & 32146 & 38307 \\
\cline { 2 - 9 } & 2015 & 1 & 36357 & 54258 & 16139 & 19652 & 35914 & 42888 \\
\hline \multirow{2}{*}{ Belgium } & 2008 & 0 & - & - & - & - & - & - \\
\cline { 2 - 9 } & 2015 & 1 & 129640 & 134635 & 39592 & 43604 & 140572 & 152321 \\
\hline \multirow{2}{*}{ Brazil } & 2008 & 0 & - & - & - & - & - & - \\
\cline { 2 - 9 } & 2015 & 1 & 35338 & 87251 & 21688 & 25605 & 15268 & 74098 \\
\hline \multirow{2}{*}{ Denmark } & 2008 & 0 & - & - & - & - & - & - \\
\cline { 2 - 9 } & 2015 & 1 & 37924 & 62408 & 38694 & 40308 & 29516 & 88355 \\
\hline
\end{tabular}

Source: Source: UNCTAD (2010; 2016) WIR Annex Tables 